\title{
DEFEND MY CASTLE: IS THE UK IN VIOLATION OF ARTICLE 8 OF THE EUROPEAN CONVENTION OF HUMAN RIGHTS?
}

\author{
Per T Lindberg ${ }^{*}$
}

\begin{abstract}
Since the 1990s approximately 700000 properties have been repossessed in the UK by mortgagees. While encouraging its citizens to access mortgage finance, the UK government has failed to provide corresponding legal protection and an effective regulatory framework to curtail unscrupulous lenders. What, if any, is the UK government's responsibility in protecting its mortgagors from losing their homes? By utilising the relatively newfound doctrine of positive obligations, this article elaborates on the extent to which the UK may be held accountable under Art 8 of the European Convention of Human Rights. By rebutting the relevance of the private and contractual nature of the mortgage relationship, arguing for the ability to enforce socioeconomic rights and upgrading the concept of home in legal discourse, this article contends that the UK is in breach of Art 8 of the ECHR. This contention is a crucial step towards reformulating states' role and responsibility under the ECHR and, if elaborated on by the judiciary, will potentially prompt political action to reform the law of mortgages in the UK.
\end{abstract}

\section{INTRODUCTION}

Under what Hobbes labelled the 'Social Contract' ${ }^{1}$ between citizen and state, what in today's sophisticated world can both parties expect? In return for dominion the people expect protection; protection against foreign states but also from other citizens and at times even themselves. This text aims to test the boundaries of this assertion in regards to a citizen's home, acquired and deprived through mortgage finance. The housing market in the UK has developed into a powerful force to be reckoned with where mortgage finance

\footnotetext{
* LLB, University of Hull Law School. The author would like to thank Dr Whitehouse for her perspicacity and perspicuity

${ }^{1}$ Term used by T Hobbes Leviathan (London: Penguin, 1968).
} 


\section{DEFEND MY CASTLE: IS THE UK IN VIOLATION OF ARTICLE 8 OF THE EUROPEAN CONVENTION OF HUMAN RIGHTS?}

has become readily available to financially incapable individuals creating unsustainable home-ownership.

During the latter half of the $20^{\text {th }}$ century, successive governments have actively encouraged home-ownership through a range of policies including the deregulation of the financial market, leaving citizens potentially susceptible to unscrupulous lending practices. Without either adequate legal protection in repossession proceedings or an effective and potent regulatory framework to rein in miscreant lenders, mortgagors have arguably been abandoned by the state to fend for themselves. When faced with a repossession order, some have stood up and fought for their homes by turning to various legal avenues including claims that the mortgage agreement is unfair and imbalanced. ${ }^{2}$ Others have turned to the European Convention of Human Rights (ECHR) and argued that repossession amounts to a breach of Article 1 Protocol 1, the right to peaceful enjoyment of one's possessions. The courts have seen attempts to invoke Article 8 of the ECHR, the "right to respect for private life, family life and home", against the mortgagee. However, although the means of defending one's home against repossession has shifted, the end result has remained largely the same: loss of home. Since the 1990s the UK mortgage market has claimed approximately 700,000 properties through repossession. ${ }^{3}$ Naturally, this leads to questions such as, how, why and what can be done to protect the sustainability of homeownership for the UK's most vulnerable citizens. In attempting to answer these questions, this text explores an alternative route which aims to defend the mortgagor's home against unscrupulous mortgagees. This text will focus on the UK government and scrutinise its failure to protect the home-owner. Within the framework of the ECHR and its rather newfound doctrine of positive obligations, I will hold the UK accountable under Art 8 for failing to protect mortgagors' homes, as the UK has actively encouraged homeownership while providing inadequate legal protection and ineffective regulatory framework to curtail perilous lending practices; factors which conjunctively precipitate home repossessions.

The first part of this text will examine UK housing policy during the latter half of the $20^{\text {th }}$ century, financial deregulation and the legal and regulatory framework in regards to repossessions. The second part will lead on to elaborate on the ECHR doctrine of positive obligation and how this can be utilised to hold the UK accountable under Art 8. The third and final part will then elaborate on appropriate measures to take and their potential effects on the housing market as a whole.

${ }^{2}$ For arguments of unfair terms see eg Falco Finance Ltd $v$ Gough (October $28^{\text {th }}$, 1998, Macclesfield County Court, unreported).

${ }^{3}$ Summarised from data provided by the Council of Mortgage Lenders, available at http://www.cml.org.uk/cml/statistics. 


\section{UK HOUSING POLICY}

By direct and indirect encouragement, successive governments have steered the UK towards what the Conservative government in 1955 labelled a 'property-owning democracy'. ${ }^{4}$ Today, the housing market consists of just over $70 \%$ home-owners ${ }^{5}$ as compared with around $10 \%$ at the beginning of the twentieth century. ${ }^{6}$ Why this radical increase? During the Inter-War period Chamberlain summated the rationale behind encouraging homeownership by asserting that "every spadeful of manure dug on, every fruit tree planted, converted a potential revolutionary into a citizen". 7 In other words, as a home-owner you were anchored to society, preferring the status quo thus bringing greater stability to the polity as a whole. The snowball had now started rolling and soon home-ownership was propagated into a deep-rooted desire in every citizen's heart. ${ }^{8}$ Thus, housing policy became a pivotal ingredient in both the Conservatives as Labours' electoral campaigns during the 1950s-1990s. Importantly, increased home-ownership and decreased public rented housing effectively shifted housing responsibility from the state to the individual.

So what have the $20^{\text {th }}$ century governments actually done to encourage and enable its vast majority of citizens to buy their home? In a nutshell, the government has gradually but effectively sold off its own housing stock and fiscally incentivised its citizens towards house purchase. Vehicles were launched to encourage first-time buyers into the market ${ }^{9}$ and schemes of subsidising interest-payments, such as Mortgage Interest Tax Relief (MITR) or Income Support for Mortgage Interest (ISMI), were increasingly used to

\footnotetext{
${ }^{4} \mathrm{~N}$ Harris Competition and the Corporate Society (London: Methuen, 1972).

5 Stephens et al Housing Market Recessions and Sustainable Home-Ownership (Joseph Rowntree Foundation, July 2008) p 3.

${ }^{6}$ A Murie "Secure and Contended Citizens? Home ownership in Britain", in A March and D Mullin Housing and Public Policy: Citizen, Choice and Control (Open University Press, 1998) p 81.

${ }^{7}$ Argued in The Times 1920, see K Feiling The Life of Neville Chamberlain (London: Macmillan, 1946) p 86.

8 See the wording of 1971 White Paper Fair Dealing for Housing "Home ownership is the most rewarding form of housing tenure"; Labour government's 1977 Housing Policy Review: "For most people ones home is a basic and natural desire...The widening entry into home ownership will help solve housing problems...as well as satisfying deep seated social aspirations "; or the Conservative Secretary of State for the Environment, Michael Heseltine in 1980 (Hansard): "There is in this country a deeply ingrained desire for home ownership."

${ }^{9}$ Local Government Act 1974 allowed local authorities, new towns and housing associations to grant low-start mortgages where capital and interest payments were deferred for two years.
} 
incentivise mortgage finance take-up. However, it was not until the instigation of Thatcher's government in 1979, that home-ownership policies really evolved.

\section{a) Right to Buy}

The 'Right to Buy' scheme under the Housing Act 1980 proved particularly effective in the pursuit of a property-owning democracy. It provided council tenants with a discount, its percentage depending on the type and duration of tenant tenure, and a right to a mortgage. Simultaneously, rents and subsidy arrangements for public renting were being restructured. Instead of a 'needs-test', a 'means-test' was employed to raise rents for the better-off council tenants. Suddenly, a vast amount of council tenants became ineligible for public housing subsidies but conveniently qualified for MITR to buy their home under the 'Right to Buy' scheme.

\section{b) Residualisation}

One significant consequence of governmental encouragement towards home-ownership is the development of 'residualisation'. ${ }^{10}$ By selling off publically owned properties, especially the more appealing and sustainable ones in better and safer areas, the public-rented sector transformed from an acceptable housing choice to a 'welfare net' for the least well-off. ${ }^{11}$ This is important since it, in itself, also incentivises home-ownership. We must not forget that an individual's feeling of 'home' need not depend upon ownership, per se; rather, the sense of security, comfort and even pride home-ownership might bring. The UK housing policy ensured that these qualities would be difficult to find in public-rented accommodation.

\section{c) Financial Deregulation}

Realising that it takes more than active encouragement from the government to increase home-ownership, the Thatcher government started deregulating the financial market to, among other aims, assure the availability of mortgage finance. To end the Building Societies' monopoly, the Conservative government abolished the direct monetary and exchange controls on the banks. This wider financial liberating measure had enormous

\footnotetext{
10 Term established by R Forrest and A Murie Right to Buy? Issues of Need, Equity and Polarisation in the Sale of Council Houses (Bristol: School for Advanced Urban Studies, 1984).

${ }^{11}$ Ibid, see Ch 5 .
} 
influence on the mortgage market as it effectively eradicated the "corset" ${ }^{\text {, }}$ which in turn opened the floodgates to banks. With banks entering the mortgage market, interest rates immediately adhered to market determined rates and the banks' near unlimited access to wholesale funding radically increased the growth of mortgage lending. ${ }^{13}$ A mounting mortgage market quickly attracted centralised lenders, most often subsidised by foreign banks, to enter the market. In contrast to the banks, the Building Societies were statutory restrained to advance mortgage finance through wholesale funding which put them at a severe competitive disadvantage. To level the market, the Building Societies Act (BSA) 1986 and 1997 permitted an increased share of wholesale funding to $50 \%$.

The deregulated mortgage market assured greater access to mortgage finance for potential home-owners, both in terms of eligibility and quantity. ${ }^{14}$ Kleinman and Whitehead predicted in 1988 that approximately one third of the increase of home-ownership in the 1980s could be attributed to financial deregulation. Introducing banks into the mortgage market effectively provided more generous lending criteria and higher loan-to-value ratio. The deregulation of the mortgage market had the effect of increasing sub-prime and self-certified lending, contributing to a vulnerable housing market. By the 1990s, the housing market had become a fungible market where an Englishman's home had become part of the financier's asset pool; the homeowner had strayed from a citizen to a consumer. ${ }^{15}$ Financial deregulation prompted financial volatility and exacerbated the boom-bust cycle in the housing market. ${ }^{16}$

${ }^{12}$ The "corset" (Special Supplementary Deposits Schemes) limited or inhibited the banks' ability to enter the savings and mortgage market as they were not allowed to expand their interest bearing liabilities.

${ }^{13}$ Between 1981 and 1991, the number of home-owners grew by 31\%. J Ford "As safe as Houses?” in G Goodwin and C Grant Built to Last? Reflection on British Housing Policy (Nottingham: ROOF Magazine, $2^{\text {nd }}$ ed, 1997) p 188.

${ }^{14}$ M Kleinman and C Whitehead "British Housing since 1979: has the system changed?” (1988) 3 Housing Studies 3.

${ }^{15}$ A concept argued by L Whitehouse “The Home-Owner: Citizen or Consumer?” in S Bright and J Dewar (eds) Land Law: Themes and Perspectives (Oxford: Oxford University Press, 1998) p 183.

${ }^{16}$ D Dale-Johnson and S Gabriel "Introduction: Deregulation and Reform of Housing and Housing Finance Markets: Recent Lessons from Western and Central Europe" (1995) 23 Real Estate Economics 396. 


\section{d) Retreat}

Unsurprisingly, the housing bubble, facilitated if not created by these housing policies and financial deregulation, burst in the early 1990s. Between 1991-1994 one in every five households were unable to pay their mortgage. In the mid 1990s over a million households faced negative equity and repossessions became a reality for at least 1000 households a week. ${ }^{17}$ Despite this, the Conservative government effectively restrained the subsidies that had allowed for the radical increase of unsustainable home-ownership. These policies emphasised that mortgagors should not rely on government safetynets, but take care of themselves. ${ }^{18}$ As Murie reflectively stated "the role of the state had permanently diminished". ${ }^{19}$

Nevertheless, despite financial incentives and safety-nets being substantially reduced during the mid- to late 1990s, the positive encouragement of home-ownership remains constant. Indifferent to its unsustainability, the current government is seeking to expand the homeownership sector beyond its current $70 \%$ level to $75 \% .{ }^{20}$ Current housing policy aims to increase the annual inflow of home-owners from 140,000 to 200,000, amounting to a net increase of one million home-owners between $2005-2010 .^{21}$

\section{e) Summing up}

Mortgage incentives and support, financial deregulation, demunicipalisation and privatisation enabled lending to ill-suited individuals which became the final thrust towards a housing market dominated by homeowners. With the dream of a property-owning democracy, the governments of 1950-2000s had effectively pushed the UK housing market towards a deregulated market based system, a beast that proved hard to contain. To what extent, however, does the law afford protection against this development?

\footnotetext{
17 P Malpass “The unravelling of Housing Policy in Britain” (1996) 11(3) Housing Studies 469.

18 See J Ford “As Safe as Houses?” in G Goodwin and C Grant Built to Last?, above n 13, p 192.

19 A Murie “The Modernisation of Housing in England” (2009) 100 (4) Tijdschrift voor Economische en Sociale Geografie at 544.

${ }^{20}$ Communities and Local Government, 2007, noted in Stephens et al Housing Market Recessions and Sustainable Home-ownership, above n 5, p 3.

${ }^{21}$ Ibid, p 20.
} 


\section{WHEN THE INK IS DRY}

Despite ever evolving socio-economic ambiances that have during the $20^{\text {th }}$ century transformed the social function of mortgages, from a device by which landowners release capital ${ }^{22}$ to a mechanism which has secured widespread home-ownership across the UK, the law of mortgage has remained extraordinarily static. What is particularly noteworthy, and according to Whitehouse the very reason why the law of mortgage has been able to remain static, is the overall lack of law governing and defining the mortgage relationship, rendering the device adoptable to varying social functions. ${ }^{23}$ Indeed, the law is predominantly concerned with outlining the formalities and procedures that create the legal device of mortgage, ${ }^{24}$ however, remain silent as to the contours of the actual mortgage relationship. This legal vacuum has been filled by "contractual negotiations", limited judicial discretionary powers and non-legal regulatory frameworks. ${ }^{25}$ Through 'contractual negotiations' the particulars, for instance, the amount of interest, length of repayments, insurance or arrears provisions of the mortgage relationship are defined. However, to suggest that the mortgage contract is an outcome of contractual negotiations or bargaining is wholly illusory. Rarely, if ever, has the mortgagor any say in the contractual terms. What is more, in order to retain control of the mortgage relationship, the mortgagees adopt 'standardised' mortgage contracts, which effectively unarm any reliance on consumer protectionist models, leaving the mortgagors with little choice in the matter. This enables the mortgagees to exert considerable control over the content of the mortgage contract, by, for instance, making mortgagors liable for costs incurred by enforcement procedures initiated by the mortgagee. Despite the imbalance of power in the mortgage relationship, the law has refused to intervene in the contractual freedom of the parties. This imbalance becomes amplified the moment the mortgagor defaults on his contractual obligations. As NACAB stated in 1993, "once in arrears, they [the borrowers] find that the

${ }^{22}$ See B Rudden “The Mortgagee’s Right to Possession” (1961) The Conveyancer and Property Lawyer 278.

${ }^{23}$ L Whitehouse "A Longitudinal Analysis of the Mortgage Repossession Process 1995-2010: Stability, Regulation and Reform” in S Bright (ed) Modern Studies in Property Law: Volume 6, (Oxford: Hart Publishing, Forthcoming).

${ }^{24}$ Law of Property Act 1925 ss 85(1) and 86(1) as amended by Land Registration Act 2002 s 23(1)(a).

${ }^{25}$ L Whitehouse, above n 23. 


\section{DEFEND MY CASTLE: IS THE UK IN VIOLATION OF ARTICLE 8 OF THE EUROPEAN CONVENTION OF HUMAN RIGHTS?}

balance of rights and responsibilities has shifted firmly in favour of the lender". ${ }^{26}$

In law, the mortgagee holds an inherent right to possession "as soon as the ink is dry" 27 on the mortgage document. In practice, the mortgagee will abstain from doing this unless the mortgagor has breached any of his/her contractual obligations, a practice that makes business sense as mortgagees are generally involved with money lending, not property dealing. However, where the mortgagor does fall behind on payments, the right to possession is habitually utilised by mortgagees to facilitate their statutory right to sell ${ }^{28}$ the mortgaged property and recover the outstanding debt. To assure a vacant sale, the mortgagee requires possession. This is predominately achieved through a court order to avoid criminal liability under S 6 of the Criminal Justice Act 1977. However, importantly, a court order is not required to repossess, as the academically infamous ${ }^{29}$ case of Ropaigealach ${ }^{30}$ perspicuously illustrated.

It is during these court proceedings that the mortgagee's attempt to realise their security finds its first potential hurdle. Under S 36 of the Administration of Justice Act (AJA) 1970, the judge is awarded some leeway to intersect in the repossession process. S 36 AJA 1970 allows the judge to adjourn, stay or suspend the proceedings for repossession "if it appears that the mortgagor is likely to be able within a reasonable period" to pay the "sums due". At its birth, several difficulties arose out of the inadequate and equivocate drafting of S 36, particularly in regards to the meaning of 'sums due' and 'reasonable period'. However, this was promptly remedied both through statutory implementation and common law. The case of Clark ${ }^{31}$ and S 8 of the Administration of Justice Act 1973 defined any 'sums due' as "only such amounts as the mortgagor would have been required to pay if there had been such provision for earlier payment”. Later, in Norgan, ${ }^{32}$ the court rectified the 'reasonable period' ambiguity by establishing the starting point to be the remainder of the mortgage life. Accordingly, if a mortgagor falls into arrears

\footnotetext{
${ }^{26}$ National Association of Citizens Advice Bureaux Dispossessed (NACAB: London, 1993) p 1.

${ }^{27}$ Four-Maids Ltd v Dudley Marshall (Properties) Ltd [1957] Ch 317, per Harman J.

28 Law of Property Act 1925, s 101: This right is implied into every mortgage agreement and becomes operable as soon as certain conditions are met (LPA 1925, s 103).

29 See M Dixon “Sorry, we've sold your Home: Mortgagees and their Possessory Rights” (1999) Cambridge Law Journal at 281, where he argues that Ropaigealach revealed a lacuna in s 36 (AJA 1970) which may spark new interest in self-help amongst dubious lenders.

${ }^{30}$ Ropaigealach v Barclays Bank plc [2000] 1 QB 263.

${ }^{31}$ Halifax Building Society v Clark [1973] 2 WLR 1.

${ }^{32}$ Cheltenham and Gloucester Building Society v Norgan [1996] 1 All ER 449.
} 
after three years in a 25-year mortgage, the court had now the discretion to spread the payments of the arrears over the remaining 22 years of the mortgage. Crucially, however, the judge is only permitted to exercise this discretion if the mortgagor can prove, beyond doubt, a financial capability of meeting their mortgage obligations; ie as long as arrears are proven, there lies a presumption in favour of the mortgagee. What is noteworthy here is that the underlying rationale of S 36 AJA 1970 appears to be exclusively concerned with the financial aspects of the mortgage relationship, which puts the mortgagor in a severe disadvantage. S 36 is uninterested in the conduct of the parties prior to court proceedings, insensitive to the reasons for the arrears, and oblivious to the social ramifications repossession might entail. S 36's tunnel-visioned approach is evident in the time it takes for the county courts to deal with possession proceedings. The Citizens Advice Bureau's December 2007 report, Set up to fail, revealed that most possession proceedings take no more than ten minutes to conduct. ${ }^{33}$ Although an increase from the mere average of five minutes it took during the financial crisis of the early $1990 \mathrm{~s},{ }^{34}$ it still showcases the simplistic approach taken by the courts when determining whether to grant, suspend or adjourn possessions. As the NACAB regrettably reflected in 1993, "[b]orrowers can find that the hearing at which they lose their home is shorter than the appointment they would be given by their local GP ...”35

Consequently, whereas the court judge is afforded very limited discretion in possession proceedings, the mortgagees retain their law-given right to decide when and how to take possession. What is more, evidence suggests that court proceedings are often pursued by mortgagees to entice repayment of monies owed and not to actually take possession of the property. ${ }^{36}$ This 'debt recovery' strategy exacerbates the mortgagor's situation as they are often contractually bound to pay court fees and ancillary administrative costs. ${ }^{37}$

The repossession process illustrated above has given rise to widespread academic and judicial criticism. Whitehouse accentuates that the "district judges afford the economic interests of the mortgagee a disproportionate

${ }^{33}$ Citizens Advice Bureau Set Up To Fail: CAB Clients' Experience of Mortgage and Secured Loan Arrears Problems, December 2007, para 4.6.

${ }^{34}$ NACAB, above n 26, p 28.

35 Ibid.

${ }^{36}$ See Citizens Advice Bureau et al Turning the tide? Evidence from the free advice sector on mortgage and secured loan possession actions in England in July 2009, December 2009; L Whitehouse "The Mortgage Arrears Pre-Action Protocol: An Opportunity Lost” (2009) 72 (5) Modern Law Review at 810.

${ }^{37}$ Court fees are typically around $£ 600$ per hearing. L Whitehouse, ibid. 


\section{DEFEND MY CASTLE: IS THE UK IN VIOLATION OF ARTICLE 8 OF THE EUROPEAN CONVENTION OF HUMAN RIGHTS?}

degree of protection" 38 and Omar asserts how clearly "the creditor is to be preferred in any balancing exercise". ${ }^{39}$ Indeed, numerous doubts have been cast upon the centuries old mortgage law truism that possession is an inherent right of the mortgagee. As Dixon questions, "if the mortgage really is no more than security for money lent, why should the manner of its creation ... grant one of the parties a pre-eminent right to the land rather than a controllable remedy for its enforcement?" 40 Rather, Dixon suggests, along with several academic colleagues, the right to possession should be transformed into a genuine remedy, enforceable through a court order. This would arguably strike the correct balance between the rights of the mortgagee and mortgagor.

Although there have been and still are strong academic claims in respect of the inadequacy of the legal protection afforded to residential mortgagors, Whitehouse correctly informs us that the mortgagor's vulnerability primarily emanates from a "complete failure by the central government to regulate the activities of mortgagees". ${ }^{41}$ As we have seen above, the ultimate decision to repossess lies with the mortgagee and it is the failure to regulate this discretion that has allowed the disproportionate power relationship to exacerbate within the mortgage relationship. ${ }^{42}$ Although Whitehouse made this claim before the establishment of today's regulatory framework (discussed below), as this framework is not regulated by law and merely serves as guidelines through 'administrative fiat', the assertion still holds a substantial truth.

\section{REGULATION - REGULATE!}

The Conservative governments of 1979-1997 relied on market forces to 'self-regulate' the mortgage market through choice and competition. ${ }^{43}$ As long as there is competition in the market there was choice and these two

38 L Whitehouse "The Impact of Consumerism on the Home Owner" in D Cowan Housing: Participation and Exclusion. Collected Papers from the Socio-Legal Studies Annual Conference 1997 (Aldershot: Ashgate, 1988) pp 138 -139.

39 P Omar "Recovery of secured property by mortgagees: the balance of interests" (2005) 16(11) International Company and Commercial Law Review, at 445.

${ }^{40}$ M Dixon, above n 29, at 283.

${ }^{41}$ L Whitehouse, above n 38, p 127.

42 Ibid.

43 This is evident through a number of deregulatory measures taken by the Conservatives since the 1980s, including the Building Societies Act 1986 and 1997, the purpose of which was to increase scope and availability of mortgage finance to bring "healthy competition into housing and finance" (The former Economic Secretary to the Treasury, Ian Stewart, (HC Deb (1985-6), 89, c 592). 
would secure adherence to consumer preferences and protection. As the housing crisis of early 1990s illustrated, this was clearly not enough.

It was not until 1997, with the repercussions of the 1990s housing crisis still raw, that the Council of Mortgage Lenders (CML) published their first Statement of Practice on the management of arrears and repossessions. It would take another seven years, with the new regulatory structure under the Financial Services Authority (FSA), for the government to provide a statutory framework for repossessions in regards to first mortgages. However, even though implemented under statute, the Mortgage Conduct of Business (MCOB) Sourcebook is a non-legal code of practice which mortgagees hold no legal obligation to comply with. Succinctly, MCOB 13 sets out rules, guidelines and evidentiary provisions of how to adequately, reasonably and equitably deal with cases of arrears and repossessions. Needless to say, as the MCOB code of practice lacks legal backing it is unfortunately neither consistently nor uniformly followed by mortgage providers. ${ }^{44}$ Regrettably, the FSA has been impotent to date in ensuring uniform and consistent adherence to MCOB 13, particularly amongst sub-prime, specialist lenders. ${ }^{45}$ Shelter has remarked that the variation of practices amongst lenders has resulted in a 'lender lottery' where some borrowers have been "particularly vulnerable to harsh and unfair treatment". ${ }^{46}$ The failure to impose uniform regulatory compliance proves the FSA's inability to regulate lenders effectively. ${ }^{47}$

\footnotetext{
${ }^{44}$ Citizens Advice Bureau Mortgage Remedies (Possession and Sale) Review Lines of Inquiry: Response by Citizens Advice to the Ministry of Justice (London: Citizens Advice, January 2009) 13 and Financial Services Authority Mortgage Effectiveness Review: Arrears Findings (Illuminas, London, Research Report Project no 30895, August 2008).

45 See Financial Services Authority Mortgage Effectiveness Review: Arrears Findings, above n 44; Mortgage Market Review, October 2009; and joint research undertaken by AdviceUK, Citizens Advice, Money Advice Trust and Shelter Mortgage and secured loan arrears: Adviser and Borrower Surveys April 2009, May 2009.

46 House of Commons Treasury Committee Mortgage arrears and access to Mortgage Finance Fifteenth Report of Session 2008-09, Ev 132 para 3.

47 This failure has prompted the FSA to propose to convert MCOB 13 forbearance guidelines into binding rules. This, the FSA hopes, will assure greater forbearance amongst mortgage lenders and ultimately curb the continuing rise of mortgage repossessions. However, while the effort is laudable, it is far from satisfactory as it will not deal with the ultimate problem, which is the FSA's inability to monitor and enforce compliance. See Financial Services Authority, Mortgage Market Review: Arrears and Approved Persons January 2010.
} 


\section{DEFEND MY CASTLE: IS THE UK IN VIOLATION OF ARTICLE 8 OF THE EUROPEAN CONVENTION OF HUMAN RIGHTS?}

\section{a) The Pre-Action Protocol}

The latest attempt to regulate the mortgage market in regards to repossession was brought about as a result of the current financial crisis. With the rapid increase of mortgage repossessions since the beginning of 2008, ${ }^{48}$ the Civil Justice Council implemented the Pre-Action Protocol for Possessions Claims Based on Mortgage or Home Purchase Plan Arrears in Respect of Residential Property (the Protocol), in November 2008. I shall not go into its details here as this has been adequately dealt with elsewhere, ${ }^{49}$ however, suffice it to say that upon closer examination it serves rather as a reflection, or reminder, of MCOB. The lack of compulsory wording and sanctions for non-compliance are the main reasons why the Protocol has been argued to constitute an 'opportunity lost' ${ }^{50}$ in answering the concerns of poor arrears management and premature repossession proceedings. ${ }^{51}$ The Financial Services Consumer Panel has proclaimed the Protocol to be 'relatively toothless' and "lack . . . clarity about how much judges can take failure to keep to these rules into account in a possession action". ${ }^{52}$ Evidence in support of these claims has been offered by Citizens Advise Bureau et al.'s December 2009 report, Turning the Tide?, ${ }^{53}$ which summates data drawn from interviews with client advisors in 452 repossession cases in July 2009. The report concluded that in a third of recorded cases $^{54}$ the advisers considered the lenders had not complied with the Protocol. ${ }^{55}$ Although I would not go as far as McAuslan in claiming that the Protocol is a "complete waste of time and paper", ${ }^{56}$ there is however no doubt that more must be done in order to curtail unscrupulous mortgagees.

\footnotetext{
48 40,000 repossessions in 2008, 46,000 in 2009, estimated 53,000 in 2010, see repossession statistics from Council of Mortgage Lenders, available at http://www.cml.org.uk/cml/media/press/2541.

${ }^{49} \mathrm{~L}$ Whitehouse, above $\mathrm{n} 36$, at 793.

50 Ibid.

51 See also P McAuslan “Mortgage arrears: the repossession crunch” (2009) 24 (3) Journal of International Banking and Finance Law.

${ }^{52}$ House of Commons Treasury Committee, above $n$ 46, Written evidence from the Financial Services Consumer Panel, Ev 151 paras 5-6.

${ }^{53}$ Citizens Advice Bureau, Shelter, Advice UK, Turning the tide?, above n 36.

54101 out of 300 cases.

${ }^{55}$ Citizens Advice Bureau, Shelter, Advice UK, Turning the tide?, above n 36, p 12 .

${ }^{56}$ P McAuslan, above n 51, at 138.
} 


\section{b) Summing up}

Consequently, not only is the law governing repossession proceedings inert, it provides disproportionate protection to the mortgagee's economic interests. The law leaves no scope for deliberations into extenuating circumstances or considerations of the psychological and social ramifications repossessions might entail. What is more, the regulatory framework in place has proven to be a meretricious code of practice filled with terms that provide no effective curtailment of questionable lending practices. With that in mind, the question we must now ask is, can we hold the UK accountable for its failure to protect financially vulnerable mortgagors from losing their homes? The following section will elaborate on this by utilising the European Convention of Human Rights' jurisprudential doctrine of positive obligation, as applied to Art 8.

\section{POSITIVE OBLIGATIONS UNDER THE ECHR}

The European Convention of Human Rights (ECHR) is generally concerned with curtailing state actions from interfering with individual rights, what we understand as negative obligations. However, the Convention demands also, explicitly or impliedly, positive obligations upon the state; ie obligations to take positive measures to protect individual rights. The right to free legal representation (Art 6) or the right to education (Art 2 of Prot 1) provide examples of where positive steps are required to be taken by the state.

Kenna illuminates the neo-liberal economic and social policy approach which has dominated the political landscape in much of the western world since the 1980s, contributing to a "rolling back of the state, reduction and privatisation of welfare services". ${ }^{57}$ This in turn has impelled the European Court of Human Rights (ECHR) to step in and remind the state of its responsibilities towards its people. Starmer directs us to the fact that the raison d'être of establishing the ECHR was not only to protect us from an 'over-mighty' government, but also to safeguard 'human dignity' ${ }^{58}$ With the aftermath of the Second World War, we were not content with theoretical or superfluous rights; rather, we wanted potent and effective protection. This has

57 P Kenna "Housing Rights: positive duties and enforceable rights at the European Court of Human Rights” (2008) 2 European Human Rights Law Review, at 196. See also Doherty et al The Changing Role of the State: State Intervention in Welfare and Housing, (Brussels: FEANTSA, 2003); S Strange “The Declining Authority of States" in Held et al (eds) The Global Transformation Reader (Cambridge: Polity Press, 2nd ed, 2003) Ch 11.

${ }^{58}$ K Starmer "Positive Obligations under the Convention” in J Jowell and J Cooper Understanding Human Rights Principles (Oxford and Portland, Oregon, 2001) p 144. 
not gone unnoticed by the ECHR. In Plattform Ärtze fur das Leben $v$ Austria, ${ }^{59}$ Art $11^{60}$ was engaged when demonstrators were attacked by counter-demonstrators which effectively hindered their right to assembly. As Art 11 is a qualified right and the Austrian government did not in fact interfere with the applicants' rights, ie the government honoured its negative obligation; the Austrian government claimed there was no such breach. Unexpectedly, the ECHR held no support for this assertion and stated that:

"[g]enuine, effective freedom of peaceful assembly cannot . . . be reduced to a mere duty on the part of the state not to interfere ... Like Article 8, Article 11 sometimes requires positive measures to be taken ... 61

Indeed, the last two decades has experienced an increasing ECHR jurisprudential trend of recognising a doctrine of positive obligations, ${ }^{62}$ especially in regards to Art 8, "the right to respect for his private and family life, his home and his correspondence”. In Lopez-Ostra v Spain, ${ }^{63}$ the ECHR imposed a positive obligation on the local authorities to contain pollution from a waste treatment plant to protect the applicant's Art 8 rights. Similarly, in Moreno Gomez $v$ Spain, ${ }^{64}$ the state's failure to regulate nightclubs' noise disturbances violated a positive obligation to respect the applicant's home under Art 8. Further, the ECHR explicitly stated in Moldovan v Romania: ${ }^{65}$

"there may, in addition to this primary negative undertaking be positive obligations inherent in an effective respect for private or family life and the home. These obligations may involve the adoption of measures designed to secure respect for these rights even in the sphere of relations between individuals . ..,"66

59 [1988] 13 EHRR 204.

60 Right to peaceful assembly.

${ }^{61}$ Plattform Ärtze fur das Leben v Austria, above n 59, para [32].

62 Guerra and Others v Italy [1998] 26 EHRR 357; Z and Others v UK [2002] 34 EHRR 97; On the right to housing: Selcuk and Asker v Turkey [1998] 26 EHRR 477; Bilgin v Turkey [2003] 36 EHRR 50; Dulas v Turkey Judgment of 30 January 2001, Application no. 25801/94; Orhan v Turkey Judgment of 18 June 2002, Application no. 25656/94; James and Others v UK [1986] 8 EHRR 123; Mellacher and Others $v$ Austria [1990] 12 EHRR 391.

63 [1994] 20 EHRR 277.

64 [2004] 41 EHRR 40.

65 [2005] 44 EHRR 16.

66 Ibid, para [93]. 
This is an important statement as rights under the Convention are only enforceable vertically, ie against public bodies, and not horizontally, between private parties. Yet, the ECHR has vehemently maintained that where private parties' action adversely affect another private party's Convention rights due to inaction by the state, the state may be held liable via the doctrine of positive obligations. ${ }^{67}$ As Starmer espouses, the fact that the ECHR imposes positive obligations upon the state is now flagrant, rhetorically, he rather questions when and to what extent. ${ }^{68}$

\section{a) Respect, Protect and Fulfil}

In 1980, Shue famously introduced an alternative way to frame states' Human Rights obligations by asserting a tripartite typology: 'to avoid depriving', 'to protect from deprivation' and 'to aid the deprived'. ${ }^{69}$ Eide later built on this thought and formulated the tripartite terminology of defining state obligations to respect, protect and fulfil. ${ }^{70}$ To respect requires the state to refrain; protect to prevent; and fulfil to take appropriate legislative, budgetary and judicial action. ${ }^{71}$ For our purposes, Eide informs us that the obligation to protect:

"requires from the State and its agents the measures necessary to prevent other individuals or groups from violating the integrity, freedom of action or other human rights of the individual - including the prevention of infringements of his or her material resources". ${ }^{72}$

67 See also Powell and Rayner v UK A/172 [1990] 12 EHRR 355, Hatton and Others $v$ UK [2003] 34 EHRR 1.

${ }^{68}$ K Starmer, above n 58, p 140.

${ }^{69}$ H Shue Basic Rights: Subsistence, Affluence and U.S. Foreign Policy (Princeton University Press, $2^{\text {nd }}$ ed, 1996) p 52.

70 A Eide "Realisation of Social and Economic Rights and the Minimum Threshold Approach” (1998) 10 Human Rights Law Journal. See E Koch's criticism of the tripartite typology in “Dichotomies, Trichotomies or Waves of Duties?” (2005) 5(1) Human Rights Law Review, where she cynically argues that the only viable components in the tripartite typology are the first and last one as they are the only ones that discusses the relationship between the individual and state, thus rendering the typology merely a reformulation of the negative/positive dichotomy.

71 See further typologies, quadruple approach by van Hoof "The Legal Nature of Economic, Social and Cultural Rights: A Rebuttal of Some Traditional Views” in P Alston and K Tomasevski The Right to Food (Netherlands : Martinus Nijhoff, 1984) p 106; Quintuple approach by H Steiner and P Alston, International Human Rights in Context (Oxford: Oxford University Press, 2nd ed, 2000) p 182.

${ }^{72}$ A Eide, above n 70, at 37. 


\section{DEFEND MY CASTLE: IS THE UK IN VIOLATION OF ARTICLE 8 OF THE EUROPEAN CONVENTION OF HUMAN RIGHTS?}

This approach is enshrined in ECHR jurisprudence through cases such as Lopez-Ostra, Moreno Gomez and Moldovan where states were rendered liable under Art 8 (1) for failure to adequately regulate the behaviour of private actors.

\section{b) Enforceability of Socio-Economic Rights}

Before embarking upon the applicability of the ECHR doctrine of positive obligation to the UK's failure to protect mortgagors from the deprivation of their home, I want to spare some words on rebutting extensive contentions that socio-economic rights are unenforceable, inapplicable ${ }^{73}$ or even legally invalid. ${ }^{74}$ It is true that socio-economic rights do not match the level of precision as do their civil and political counterparts, ${ }^{75}$ mainly due to the fact that socio-economic rights are more positive in nature, thus requiring state resources. ${ }^{76}$ Enforcing socio-economic rights is said to have a society-wide impact, going beyond the 'triadic' adversarial dispute, with inevitable budget implications. As Ngwena argues, socio-economic rights are 'preponderantly polycentric' ${ }^{77}$ Indeed, socio-economic rights, being inherently polycentric and resource demanding, fall traditionally within the reign of the democratically elected legislative or executive branches of government rendering judicial review potentially an illegitimate intrusion of the doctrine of separation of powers. However, such a rigid and formalistic approach does not correspond with reality, nor is it preferable. While it is true that the primary role of the judiciary is not to make decisions concerning distribution of national resources, it would be naive to think that the courts never engage in such undertaking. Indeed, Lord Steyn has extra-judicially contended:

73 See M Scheinin “Economic and Social Rights as Legal Rights” in Eide et al Economic, Social and Cultural Rights, (Dordrecht: Martinus Nijhoff, 2001) pp 29-54. 74 See CR Sunstein “Against Positive Rights” (1993) 35 East European Constitutional Review.

75 See C Scott and P Macklem "Constitutional Ropes of Sand or Justiciable Guarantees? Social Rights in a New South African Constitution” (1992) 141 University of Pennsylvania Law Review 1, where they contend that "social rights often suffer from a painful lack of precision with respect to the nature and extent of obligations that attach to the state party".

76 See M Tuchnet "Social Welfare Rights and the Forms of Judicial Review” (2004) 82 (7) Texas Law Review.

77 C Ngwena "Access to Antiretroviral Therapy to Prevent Mother-to-Child Transmission of HIV as a Socio-economic Right: An Application of Section 27 of the Constitution” (2003) 18 South Africa Public Law, at 87. 
"Most legislation is passed to advance a policy. And frequently it involves in one way or another the allocation of resources... What I am saying is that there cannot be a legal principle requiring the court to desist from making a judgment on the issues in such cases... There is in my view no justification for a court to adopt an a priori view in favour of economic conservatism. In common law adjudication, it is an everyday occurrence for courts to consider, together with principled arguments, the balance sheet of policy advantages and disadvantages. It would be a matter of public disquiet if the courts did not do so. Of course in striking the balance courts may arrive at result unacceptable to Parliament. In such cases Parliament can act with great speed to reverse the effect of a decision. That is in the spirit of our constitution, and is wholly in accord with the democratic ideal. But there is no need to create a legal principle requiring the courts to abstain from ruling on policy matters or recourse allocation issues." ${ }^{78}$

Furthermore, both civil-political rights and socio-economic rights are 'positive' and 'negative' in nature, requiring, albeit to varying extents, allocation of resources. On top of this, socio-economic rights are ". . . indissoluble linked to civil and political rights: together these citizens' rights and accompanying duties constitute the cornerstone of a free democratic society founded on respect for human rights."79 This link is apparent within Art 6 ECHR jurisprudence, 'the right to a fair trial'. Although a civil right in nature, Art 6 has a recognised social dimension, being the right to free legal assistance which obliges the ECHR to examine the socio-economic context. The overlapping relationship between civil-political rights and socioeconomic rights has been explicitly recognised in the Airey ${ }^{80}$ case where the ECHR held:

"[w]hilst the Convention sets forth what are essentially civil and political rights, many of them have implications of a social or economic nature ... [T] Convention may extend into the sphere of social and economic rights should not be a decisive factor against such an interpretation; there is

\footnotetext{
${ }^{78}$ Lord Steyn “Defence: A Tangled Story” (2005) Public Law, at 357.

79 Opinion of the Economic and Social Committee on the Citizens' Europe, 23 September 1992, (Opinion No. 1037) para 1.2.3.

${ }^{80}$ Airey $v$ Ireland [1979] 2 EHRR 305; see also Feldbrugge $v$ the Netherlands [1986] 8 EHRR 425; Deumeland $v$ Germany [1986] 8 EHRR 448 and Salesi $v$ Italy and Schuler-Zgraggen $v$ Switzerland [1993] 26 EHRR 187 where the ECHR went further extending protection of Art 6 to social security benefits.
} 


\section{DEFEND MY CASTLE: IS THE UK IN VIOLATION OF ARTICLE 8 OF THE EUROPEAN CONVENTION OF HUMAN RIGHTS?}

no water-tight division separating that sphere from the field covered by the Convention." 81

Further, there is a related argument that courts are institutionally incompetent to adjudicate in predominately polycentric issues. ${ }^{82}$ Yet, again, this does not reflect reality as courts across several jurisdictions have proven themselves capable of dealing with polycentric issues, ${ }^{83}$ not least in the UK where we have seen a rapid development during the last decades in terms of standing and evidentiary procedures that involves polycentric public interest disputes. Indeed, as Pieterse argues, several features of the judiciary make it particularly appropriate to consider socio-economic issues. ${ }^{84}$ The judiciary retains the capability of providing individualised remedies and speedy solutions as compared to its legislative and executive counterparts. ${ }^{85}$ Well educated, experienced and impartial judges allow a rational and deliberative judicial process leading to equitable results. ${ }^{86}$ This makes the judiciary a valuable partner in assuring the states' overall commitment to socio-economic welfare. This is recognised by, for instance, Venezuela where the judiciary and the legislature, in van Beuren's words, adopts a 'constructive constitutional conversation' in order to fulfil their human rights obligations, rather than engaging in 'territorial power-struggle'. ${ }^{87}$ Similarly, the Constitutional Court in South Africa, one of the world's most progressive courts in terms of enforcing socio-economic rights, has held that "it cannot be said that by including socio-economic rights . . . a task is conferred upon the

${ }^{81}$ Airey, ibid, para 26.
${ }^{82}$ See CR Sunstein “Against Positive Rights”, above n 74; and D Beatty Human Rights and Judicial Review: A Comparative Perspective, (Martinius Nijhoff Publishers, Dordrecht, London, 1994) Ch 9.

83 See South African cases of Government of the Republic of South Africa The Premier of the Province of the Western Cape, Cape Metropolitan Council, Oostenberg Municipality v Irene Grootboom and Others [2000] 11 BCLR 1169(CC); Soobramoney $v$ Minister of Health (KwaZulu-Natal) [1998] 1 SA CC 765; Guyana case of Attorney-General $v$ Alli [1989] LRC 474; Indian cases of Olga Tellis $v$ Bombay Municipal Corp [1986] AIR 1; Paramand Kataria v Union of India [1989] 4 SCC 286; Paschim Banga Khet Mazdoor Sabha v State of West Bengal [1996] 4 SCC 37.

${ }^{84} \mathrm{M}$ Pieterse "Coming to terms with Judicial Enforcement of Socio-Economic Rights” (2004) 20 South African Journal on Human Rights 383, at 395.

85 Ibid.

86 Ibid.

${ }^{87}$ G van Beuren "Including the Excluded: The case for an Economic, Social and Cultural Human Rights Act” (2002) Public Law, at 464. 
courts so different from that ordinarily conferred ... that it results in a breach of separation of powers". ${ }^{88}$

Polycentric issues arise in almost all disputes before the courts; it is its degree that differs depending on the context. As Scott and Alston recognise, "just because a court cannot legitimately or competently deal with all - or even many - aspects of a case does not mean that it should deal with none". ${ }^{89}$ Surely, just because there is a risk of 'usurping' the role of elected officials it should not preclude judicial scrutiny of socio-economic issues altogether. ${ }^{90}$ Arguably the judiciary is expected to tip-toe around socio-economic matters to a far greater extent than it does in civil-political ones, possibly resulting in greater adherence to its democratic role within the doctrine of separation of powers.

Thus, socio-economic rights are not 'inherently' non-justiciable, rather the resistance of their judicial inclusion stems from ideological or cultural determinants or indeed political immaturity. As Scott and Macklem wrote when reflecting on the South African Constitution, justiciability is "a contingent and fluid notion dependent upon various assumptions concerning the role of the judiciary in a given place at a given time as well on its changing character and evolving capacity". ${ }^{91}$ Time and again we find what was once non-justiciable, suddenly is, as the UK courts recently experienced with the enactment of the Human Rights Act 1998. Examining ECHR jurisprudence, the ECHR have certainly begun realising that stopping short of enforcing civil-political rights no longer suffices as it has become just as important to supervise states' commitment to protect socio-economic rights, as the doctrine and jurisprudence of positive obligations evidence. Parenthetically, if we are to classify socio-economic rights as human rights it necessarily follows that there must be a mechanism which retains the jurisdiction to enforce them. As Tushnet points out, “a purported right without an accompanying judicially enforceable obligation is, almost literally, toothless". ${ }^{92}$ To deny justiciability of socio-economic rights would render the states their exclusive protectors and violators, thereby entirely stripping them of their human rights characteristics. However, although this article is not arguing a socio-economic right to a home, the doctrine of positive obligations,

${ }^{88}$ Ex parte Chairperson of the Constitutional Assembly: In re Certification of the Constitution of the Republic of South Africa [1996] 4 SA CC, para [77].

${ }^{89} \mathrm{C}$ Scott and P Alston "Adjudicating Constitutional Priorities in a Transnational Context: A Comment on Soobramoney's Legacy and Grootboom's Promise” (2000) 16 South African Journal on Human Rights, at 242.

${ }^{90}$ M Pieterse, above n 84, at 394.

${ }^{91} \mathrm{C}$ Scott and P Macklem, above n 75, at 17.

${ }^{92}$ M Tuchnet, above n 76, at 1901. 


\section{DEFEND MY CASTLE: IS THE UK IN VIOLATION OF ARTICLE 8 OF THE EUROPEAN CONVENTION OF HUMAN RIGHTS?}

whereby the state has a responsibility to protect its citizens' homes, potentially serves as a pivotal step in that direction.

Consequently, whether socio-economic rights are justiciable is not a question of institutional capacity, competence or legitimacy; it is whether we have evolved far enough in our commitment to human rights. This author holds that Europe has and if not, there are few excuses left and this article serves as one indication of the immediacy and importance of taking the next step towards securing our socio-economic human rights. With that in mind, let us examine, as Starmer would suggest, how far a state's positive obligation extends to a mortgagor's Art 8 right to respect for home.

\section{IN THE NAME OF ART 8, DEFEND MY CASTLE}

Having established the existence of an ECHR doctrine of positive obligations, this section aims to elaborate whether it can hold a state accountable, under Art 8, for failure to adequately protect its citizens' homes against private actors.

The issue of standing before the ECHR will not be discussed here as it will be dependent upon the particular facts of the instant case. ${ }^{93}$ What this text aims to elucidate is how to utilise the doctrine of positive obligation when Art 8 is invoked in regards to possession proceedings. Furthermore, this text also recognises the implication of the Human Rights Act (HRA) 1998 as it determines the UK's application and procedural rules in regards to the ECHR. $^{94}$

To reiterate, Art 8(1) states "[e]veryone has the right to respect for his private and family life, his home and his correspondence”. Being a qualified right, however, Art 8(2) states that any interference may be justified if it can be proven to be in "accordance with law and necessary in a democratic society in the interests of national security, public safety or the economic well-being of the country, for the prevention of disorder of crime, for the protection of health and morals or for the protection of the rights and freedoms of others”. These are the parameters in which we are to operate.

\footnotetext{
93 Such as time-limit and exhaustion of domestic remedies.

${ }^{94}$ Particularly HRA 1998 s 2 (1) A court or tribunal determining a question which has arisen in connection with a Convention right must take into account any - (a) judgment, decision, declaration or advisory opinion of the European Court of Human Rights, (b) opinion of the Commission given in a report adopted under Article 31 of the Convention and s 3 (1) "So far as it is possible to do so, primary legislation and subordinate legislation must be read and given effect in a way which is compatible with the Convention rights" and s 6 "It is unlawful for a public authority to act in a way which is incompatible with a Convention right".
} 


\section{c) $\operatorname{Art} 8(1)$}

The interpretation and application of Art 8 in possession proceedings have unquestionably experienced a roller-coaster ride both within the UK courts and viz-á-viz the ECHR. It is important to demarcate between possession proceedings brought by public bodies contra private actors. Starting with the House of Lords decision in Qazi ${ }^{95}$ where although the House (excluding Lord Scott) held that legally performed possession proceedings brought by public authorities engaged Art 8 (1), there were differences as to whether 'contractual and proprietary rights' could be defeated by an Art 8(2) defence. The majority ${ }^{96}$ held that it, unequivocally, could not. As soon as the possession proceeding was in accordance with law, there was nothing more to investigate in terms of proportionality or justification. ${ }^{97}$ This approach clearly deviates not only from previous domestic case-law, ${ }^{98}$ but, significantly, also from ECHR jurisprudence, ${ }^{99}$ which Lords Bingham and Steyn illuminated in their dissenting opinions. ${ }^{100}$ Contrary to the majority view, Lords Bingham and Steyn favoured Laws LJ reasoning in Sheffield City Council v Smart ${ }^{101}$ that possession proceedings amounts to a prima facie interference with the right to respect for one's home and therefore requires the court to consider whether the interference was proportionate and legitimate as per Art 8 (2). According to Laws LJ:

"'Home' is an autonomous concept for the purpose of ECHR, and does not depend on any legal status as owner . . . Since the effect of the possession orders would be to throw them out, I think it inescapable that those orders amounted to an interference with the appellants' right

\footnotetext{
${ }^{95}$ London Borough of Harrow v Qazi [2003] UKHL 43.

${ }^{96}$ Lords Hope, Scott and Millett.

${ }^{97}$ Qazi, above n 95, at para [103], per Lord Millett.

98 See UK case-law R (McLellan) v Bracknell Forest Borough Council; Reigate \& Banstead Borough Council v Benfield [2001] EWCA Civ 1510, [2002] QB 1129; Poplar Housing \& Regeneration Community Association Ltd v Donoghue [2001] EWCA Civ 595, [2002] QB 48; Sheffield City Council v Smart; Central Sunderland Housing Company Ltd v Wilson [2002] EWCA Civ 04, [2002] HLR 639.

99 See ECHR case-law Di Palma v United Kingdom [1986] 10 EHRR 149; Ure v United Kingdom (November $27^{\text {th }}$ 1996, Application No 28027/95); Marzari $v$ Italy [1999] 28 EHRR CD 175.

100 See Qazi, above n 95, Lord Bingham paras [12]-[25] and Lord Steyn paras [26][33].

101 Above n 98.
} 


\section{DEFEND MY CASTLE: IS THE UK IN VIOLATION OF ARTICLE 8 OF THE EUROPEAN CONVENTION OF HUMAN RIGHTS?}

of respect of their homes. I have said that the case is all about Article 8; more precisely, it is all about Article 8(2).,"102

In justifying his contention, Laws LJ continued:

"It concerns the relationship between the two paragraphs of Article 8 . . . The court has to arrive at a judicial choice between two possibilities, a choice which transcends the business of finding out what the legislation's words mean. The first choice . . . would entail a judgment that the Convention requirement was met at the Article 8(1) stage: on balance, taking into account all the factors . . . there was no want of respect for the appellants' homes. The second choice (accepting a prima facie violation of Article 8(1)), which I prefer, entails a judgment that the more rigorous and specific standards set out in Article 8(2) have to be met if the court is to hold that the evictions are compatible with the appellants' Convention rights. The Convention is, as it were, much more remotely engaged in the fabric of our domestic law if the first, rather than the second, choice is taken. Part of the court's task is to decide how close that engagement should be in the context in hand. I consider as a matter of substance that the vindication and fulfilment of the Convention rights, for which purpose HRA was enacted, require that the domestic law procedures involved in these appeals should be subjected to scrutiny for conformity with the Article 8(2) standards. Such a process is demanded by the fullness of our municipal law of human rights."

The majority in Qazi rejected Laws LJ reasoning holding that an unqualified right to possession cannot be put under Art 8(2) scrutiny. However, the subsequent ECHR cases of Connors ${ }^{104}$ and Blecic ${ }^{105}$ undermined the approach to Art 8 taken by the majority in Qazi while reaffirming its previous jurisprudence. In both Connors and Blecic, the applicants had no legal defence to their claim under domestic law, as the public bodies had unqualified lawful rights in taking possession; however, the ECHR engaged in extensive considerations as to Art 8 (2) justifications. ${ }^{106}$ As soon as the ECHR was satisfied that the property in question constituted a 'home' for the purpose of Art 8 the, albeit lawful, termination of their tenancy

\footnotetext{
102 Sheffield City Council v Smart, above n 98, para [26].

103 Ibid, para [27].

${ }^{104}$ Connors v United Kingdom [2004] 40 EHRR 189.

105 Blecic v Croatia [2004] 41 EHRR 185.

106 The court devoted fourteen paragraphs of its judgment in Connors to this aspect and eleven paragraphs of its judgment in Blecic.
} 
constituted an interference with their right to respect for their home, ${ }^{107}$ reminiscing the reasoning employed by Laws LJ above.

This jurisprudential inconsistency between the UK courts and ECHR reached its moment of truth in the conjoined cases of Kay and Price. ${ }^{108}$ While the seven Law Lords presiding ${ }^{109}$ concluded that the approach employed in Qazi was too wide, the majority maintained, ${ }^{110}$ in principle, the approach taken in Qazi. ${ }^{111}$ Again, Lord Bingham disagreed with the majority and held that although public bodies need not from the outset establish an Art 8 compliant possession order, as it would render the majority of cases 'burdensome and futile', it was nevertheless important to allow the possibility for occupiers to raise an Art 8 defence, should they so wish. This, Lord Bingham held, "will be in no way burdensome. In rare and exceptional cases it will not be futile." 112

The House did, however, recognise that there are circumstances, albeit highly exceptional, where lawful possession proceedings might violate Art $8{ }^{113}$ The majority, articulated by Lord Hope, established two 'gateways, 114 through which to challenge a lawful possession proceeding: the first gateway would stand as a qualified Art 8 challenge whereas the second as an application for judicial review. ${ }^{115}$ The Law Lords distinguished Connors as involving "peculiar facts and circumstances"116 as the state held a positive obligation of protecting gypsies, being "members of a vulnerable minority", ${ }^{117}$ and therefore, required further consideration. ${ }^{118}$ However, the subsequent case of McCann ${ }^{119}$ explicitly stated that Connors was not

\footnotetext{
107 See Blecic, above n 105, para [54], Connors, above n 104, para [68] .

${ }^{108}$ Kay v Lambeth LBC sub nom Price v Leeds City Council [2006] UKHL 10; [2006] 2 WLR. 570.

109 Three of which sat in Qazi, Lords Scott, Hope and Bingham.

${ }^{110}$ Lords Hope, Scott and Brown and Baroness Hale.

111 See Lord Hope in Kay and Price, above n 108, para [69] et seq.

112 Ibid, para [29].

113 Such as the facts in Connors, above n 104.

114 Term used by I Loveland in "Defending ground 8 residential possession claims through article 8 of the European Convention on Human Rights” (2009) 5 Conveyancer and Property Lawyer, at 401.

115 See the two gateways articulated by Lord Hope, Kay and Price, above n 108, at para [110].

${ }^{116}$ Lord Bingham, ibid, para [24].

${ }^{117}$ Lord Bingham, ibid, para [36].

118 See Lord Hope, ibid, para [96], Lord Scott, para [159].

${ }^{119}$ McCann v United Kingdom [2008] 47 EHRR, 40 ECHR.
} 

EUROPEAN CONVENTION OF HUMAN RIGHTS?

"confined only to cases involving the eviction of gypsies". ${ }^{120}$ Furthermore, the ECHR reiterated that:

"The loss of one's home is a most extreme form of interference with the right to respect for the home. Any person at risk of an interference of this magnitude should in principle be able to have the proportionality of the measure determined by an independent tribunal in the light of the relevant principles under Article 8 of the Convention, notwithstanding that, under domestic law, his right of occupation has come to an end." 121

Post-McCann there is an apparent judicial discomfort in regards to the UK courts' approach to Art 8 proceedings, ${ }^{122}$ particularly since the approach taken in McCann has been recently reaffirmed by the ECHR in Cosic v Croatia. ${ }^{123}$ In Cosic the applicant rented a flat by the local authority school board, who in turn leased it from the central government. When the lease between the school board and central government expired, the central government sought possession. Under Croatian law, the applicant had no other option than to vacant the flat, hence, possession order was granted. The ECHR held, however:

"...the guarantees of the Convention require that the interference with an applicant's right to respect for her home be not only based on the law but also be proportionate under paragraph 2 of Article 8 to the legitimate aim pursued, regard being had to the particular circumstances of the case." ${ }^{\prime 124}$

The abovementioned issues are dealt with in light of residential occupation where the landlord and/or owner are public bodies. Although the UK has not lived up to the standards emanating from ECHR in regards to Art 8 , crucially the laws and regulations governing the area of public renting are quite adequate and arguably strike the proportionate balance between

\footnotetext{
${ }^{120}$ Ibid, para [50].

121 Ibid, para [50], further reiterated in Cosic v Croatia (Application no 28261/06) January 15, 2009.

122 Particularly noticeable in Doherty v Birmingham City Council [2008] UKHL 57, [2008] 3 WLR 636; see also Liverpool City Council v Doran [2009] EWCA Civ 146; McGlynn v Welwyn Hatfield DC [2009] EWCA Civ 285; For analysis see, I Loveland "The New Latest Last Word on the Relevance of ECHR Article 8 to Possession Proceedings” (2010) 4 Journal of Planning and the Environment, pp 415-430.

123 Above n 121.

${ }^{124}$ Cosic v Croatia, above n 121, para [21].
} 
individual and community interests, as Lord Bingham alluded to in his Kay and Price judgment. For our purposes, the abovementioned case-law set the scene; however they do not indispensably determine the outcome, as we are dealing with inadequate law and ineffective regulation governing private actors. What the ECHR jurisprudence does suggest, however, is the increasing flexibility of the ECHR in regards to Art 8 claims. In effect, possessing one's home, notwithstanding lawful within the domestic context, is only ECHR compliant if it is proportionate to the legitimate aim pursued and answers a pressing social need. ${ }^{125}$ The next sections intend to put this into the private context in the UK by applying the doctrine of positive obligations.

\section{b) Mortgagor/mortgagee context}

An Art 8 procedure involves a three-stage process: 1) determining whether Art 8 (1) is engaged 2) determining whether Art 8 (1) is infringed and 3) determining whether the infringement is justified according to Art 8 (2).

\section{i) Is Art 8 (1) engaged?}

Importantly, in Lopez-Ostra, Moreno Gomez and Moldovan it was not the private actors' actions, per se, that amounted to an infringement of Art 8, rather, it was the actors' action coupled with the state's failure in its positive obligation to protect rights conferred under Art 8. Indeed, how can individuals single-handedly violate Convention rights of which they are not legally parties to? Consequently, in order to trigger the UK's positive obligation we must first prove that Art 8 has the capacity to be engaged by private actors, such as mortgagees. Admittedly, a crucial difference between mortgagees and the private actors in Lopez-Ostra and Moreno Gomez is the contractual relationship between the mortgagee and mortgagor, rendering state liability arguably unattainable. Undeniably, Lord Bingham held in Qazi that nothing in his judgement "should be understood as applying to any landlord or owner which is not a public authority". ${ }^{126}$ However, while reiterating this statement in Kay and Price, he further went on stating that these deliberations are "best left for resolution in a case where it arises”, ${ }^{127}$ thereby leaving the issue open. In fact, in Wood $v U K,{ }^{128}$ the commission accepted that a mortgage repossession action did engage the individual's right to respect for home, and

\footnotetext{
125 See McCann, above n 119, para [49], Connors, above n 104, para [81] and Blecic, above $n$ 105, paras [58]-[59].

${ }^{126}$ Qazi, above n 95, para [23].

${ }^{127}$ Kay and Price, above n 108, para [28], see also similar statement by Lord Nicholls at para [61].

${ }^{128}$ [1997] 24 EHRR, CD 69.
} 


\title{
DEFEND MY CASTLE: IS THE UK IN VIOLATION OF ARTICLE 8 OF THE EUROPEAN CONVENTION OF HUMAN RIGHTS?
}

attention would therefore turn to whether there was interference and if so, justified under Art 8(2). ${ }^{129}$ Accordingly, the commission held in Wood that the UK court's decision to uphold the repossession:

\begin{abstract}
"was in accordance with the terms of the loan and the domestic law and was necessary for the protection of the rights and freedoms of others, namely the lender . . . the Commission considers that this deprivation [repossession] is in the public interest ..."130
\end{abstract}

Wood never reached the ECHR as the commission held the application 'manifestly ill-founded'; ${ }^{131}$ however, notably there were no considerations as to any positive obligation conferred upon the state as this was never raised by the applicant. The route employed in Wood suggests that although repossessions by mortgagees do engage Art 8 , the state's courts and other public body's endorsement of such repossession have the capacity to interfere with Art 8 and attentions should therefore turn to Art 8(2). Poplar ${ }^{132}$ concerned a possession order issued against an assured shorthold tenant. The landlord, in this case a public body, could not obtain possession without a court order, as stipulated under the Housing Act 1988. However, the court was obliged to issue an order if the tenancy was subject to S 21(4) of the Housing Act and proper notice had been served. These conditions were duly met and focus thus shifted to Art 8 (and 6) of the ECHR. Although the court held that Art 8 was engaged and interfered with, the interference was justified under Art 8 (2). This case was later cited in McLellan and Banstead ${ }^{133}$ which concerned similar issues. In reference to Poplar, Waller LJ stated:

"even if it had been a private landlord seeking to evict a tenant under an assured shorthold tenancy, the court as a public authority would have had to approach section 21(4) of the Housing Act 1988 . . . in much the same way. It would have concluded that section 21(4) did not infringe any article 8 right but not because article 8 did not apply at all, but because the eviction was in accordance with the law . .."134 (Emphasis added)

\footnotetext{
${ }^{129}$ See also Lambeth LBC v Howard [2001] 33 HLR 58; [2001] EWCA Civ 468.

${ }^{130}$ Wood, above n 128 , para [1].

131 Ibid.

${ }^{132}$ Poplar Housing \& Regeneration Community Association Ltd v Donoghue, above $\mathrm{n}$ 98.

${ }^{133}$ R (McLellan) v Bracknell Forest Borough Council; Reigate \& Banstead Borough Council v Benfield, above $\mathrm{n} 98$.

${ }^{134}$ Ibid, para [42].
} 
Incidentally, Lord Hope considered his judgement in Kay and Price to apply equally to public and private actors. ${ }^{135}$ Thus, there are substantial grounds for arguing that a private mortgagee's repossession of a mortgagor's home engages Art 8 (1). Alternatively, Art 8 is potentially engaged in repossession proceedings in a mortgagee/mortgagor context, as the court handling the proceedings would have had to approach the common law principle of an inherent right to possession, S 101 LPA 1925 and S 36 AJA 1970, which conjunctively determine the mortgagor's security of tenure. This is correct since the courts, as public bodies, are, by virtue of S 6 HRA 1998, bound in their practice and procedures to be compatible with the ECHR. Indeed, as Sedley LJ held in Howard, ${ }^{136}$ "a legal threat to a secure home will, in the ordinary way, engage Article 8(1)."137

\section{ii) Is Art 8 (1) infringed?}

This is where we find a significant hurdle to overcome. I contend that the mortgagor has potentially suffered an infringement of his Art 8 rights due to the inadequacy of governing law and ineffective regulation which conjunctively precipitate home repossessions. ECHR case-law confirms that the Court is not afraid of holding states accountable when failing to adequately regulate private actor's behaviour. ${ }^{138}$ As academically recognised and empirically self-evident in the current economic crisis, the regulatory framework in place is inadequate and, as Whitehouse writes, lacks 'bite'. ${ }^{139}$ Without legal backing, it may even be argued to lack substance. In Moreno Gomez, the ECHR held:

"Regulations to protect guaranteed rights serve little purpose if they are not duly enforced and the Court must reiterate that the Convention is intended to protect effective rights, not illusory ones. The facts show that the applicant suffered a serious infringement of her right to respect for her home as a result of the authorities' failure to take action to deal with the night-time disturbances."

\footnotetext{
${ }^{135}$ Kay and Price, above n 108, paras [64] and [75].

${ }^{136}$ Lambeth LBC v Howard, above n 129.

${ }^{137}$ Ibid, para [32].

138 See eg Fadayeva v Russia [2005] 45 EHRR 10 and Moreno Gomez, above n 64.

139 L Whitehouse, above n 36, at 814, quoting The Law Society "Home-owners Unprotected by Weak Mortgage Protocol, Warns Law Society” (Law Society, Press Release, 2 December 2008).

${ }^{140}$ Moreno Gomez, above n 64, para [61].
} 


\section{DEFEND MY CASTLE: IS THE UK IN VIOLATION OF ARTICLE 8 OF THE EUROPEAN CONVENTION OF HUMAN RIGHTS?}

Is the failure to regulate pollution or noise from private actors a great leap away from the failure to regulate lending practices? Indeed, in the first cases, the applicants were at least able to keep living in their homes, while the latter result in the loss of home. As accentuated, the spirit of the Convention was to protect effective rights, not illusory ones. The obstacle we face is where the UK might be de jure compatible with its ECHR obligations; however, is de facto incompatible as the UK's laws and regulation governing the mortgage relationship renders Art 8 rights illusory. This is not because the laws and regulation actively interfere, rather, because they are inadequate or nonexistent. As such, the ECHR jurisprudence, particularly as applied in the UK, in itself contradicts the spirit of the ECHR. More must be done. This text's submissions are as follows: a mortgagee's right to possession, instigated by inadequate regulation, facilitated by law, and upheld disproportionately by the court, interferes with a mortgagor's Art 8 rights and requires justification under Art 8 (2).

\section{iii) Justified under Art 8(2)}

Whether the question of justification under Art 8(2) is framed in light of a 'positive duty' on the state, ie its failure to protect mortgagors, or in terms of 'interference by a public authority', the ECHR has held that the applicable principles are roughly the same. ${ }^{141}$ In both contexts, a balance has to be struck between the competing interests of the individual and of the community as a whole. Being a socio-economic right, the state generally enjoys a wide margin of appreciation as they are in the best position to know the boundaries of their capabilities and the needs of their society. ${ }^{142}$

In a mortgagor/mortgagee context, the 'economic well-being of the country' and the 'protection of rights and freedoms of others' would be the natural justifications for the state's actions, or in our case inaction. The state would invariably argue that it is within their domain to determine the appropriate measures to advance and secure the economic well-being of the country and to protect the contractual rights of the mortgagees. Loveland notes that whereas previously, most notably articulated in Court of Appeal cases $^{143}$ and in Buckley, ${ }^{144}$ the state enjoys "broad, macro-level discretion in matters of housing policy", ${ }^{145}$ however, "Connors and McCann have redefined possession cases as being concerned primarily with the micro-level

\footnotetext{
${ }^{141}$ Lopez-Ostra, above n 63, para [51], Moldovan, above n 65, para [97].

142 James and Others $v$ UK [1986] 8 EHRR 123.

143 Such as Poplar, above n 98, McLellan, above n 98, and Central Sunderland Housing Co Ltd v Janet Wilson [2002] EWCA Civ 4; [2002] HLR 639.

${ }^{144}$ Buckley v United Kingdom [1997] 23 EHRR 101.

${ }^{145}$ I Loveland, above n 114, at 404.
} 
interests of the resident and not with the political autonomy of a legislature" ${ }^{146}$ As the ECHR held in Connors, Art 8 concerns with:

"rights of central importance to the individual's identity, selfdetermination, physical and moral integrity, maintenance of relationships with others and a settled and secure place in the community. Where general scope and economic policy considerations have arisen in the context of Art 8 itself, the scope of the margin of appreciation depends on the context of the case, with particular significance attaching to the extent the intrusion into the personal sphere of the applicant." 147

This allows for greater scrutiny within Art 8 (2). What is important to note is that in line with the submissions herein, the contractual relationship between the mortgagee and mortgagor, per se, does not render the UK immune from potential breach of Art 8. As Part I demonstrated, the UK has pushed the citizen towards mortgage finance take-up, a market that imposes standardised contract terms. What is more, the law has subsequently provided disproportionate protection towards the economic interests of the mortgagee, again adversely affecting the mortgagor's Art 8 rights. Significantly, the balancing exercise is not conducted between the rights of the mortgagee as against mortgagor, rather law and regulation that determine that contractual relationship against the individual's home interest. Thus, in light of the doctrine of positive obligations, the question we must ask is: has the UK awarded sufficient legal and regulatory protection to the mortgagor's home? In line with the conventional proportionality principle employed by the ECHR, we might rephrase this question as: are the deregulatory measures of the UK and the extensive legal protection of mortgagees necessary to protect the mortgagees' contractual right and secure the economic well-being of the country? This requires the Court to engage in a balancing exercise where they are to take the interests of the home-owner and weigh those against the interests of the mortgagee and the economic well-being of the UK.

To effectively conduct this balancing exercise, however, there must be an understanding of the interests in play. Note that we are not engaging in a proprietary interest, generally protected under Art 1 of Protocol $1,{ }^{148}$ rather the interest of 'home', which is not dependent upon a classification under domestic law. ${ }^{149}$ Fox cogently argues in Conceptualising Home ${ }^{150}$ that there

\footnotetext{
146 Ibid.

147 Connors, above n 104, para [82].

148 Of the ECHR.

149 Buckley v United Kingdom, above n 144, para [63].
} 


\section{DEFEND MY CASTLE: IS THE UK IN VIOLATION OF ARTICLE 8 OF THE EUROPEAN CONVENTION OF HUMAN RIGHTS?}

has been and still is a disregard and regrettable incomprehension of the concept of home in legal discourse, which has "facilitated the subjugation of occupier's interests". ${ }^{151}$ Undeniably, the definition of 'home' is intricate and subjective. As Lawrence puts it, home is "a relative concept, not an absolute one ... Given that it transcends quantitative, measurable dimensions and includes qualitative subjective ones, it is a complex, ambiguous concept that generates confusion". ${ }^{152}$ Contrarily, the courts generally grasp the mortgagee's interest as it is readily intelligible and quantifiable. Nonetheless, as Fox submits, the courts must come to terms with the definition of home to safeguard equitable and effective legal discourse, anything else is inexcusable. Because one's home is associated with much more than its financial and structural attributes, comprising also of "multi-emotional, psychological and cultural matters", ${ }^{153}$ it leaves greater scope for the applicability of Art 8. Illustratively, in Gillow $\vee U K,{ }^{154}$ the court held that to respect the right to home was also "pertinent to their personal security and well-being". ${ }^{155}$ Though the majority in Qazi discredited 'home' to have any special meaning in law, Lord Bingham asserted that "few things are more central to the enjoyment of human life than having somewhere to live" ${ }^{156}$ Incidentally, the fact that home bears a greater meaning than an occupational interest is governmentally recognised. This can be seen, for instance, in compulsory purchase orders where local authorities are required to make a 'home loss' payment, in addition to the property value, to reflect the "emotional upset, discomfort and inconvenience" of losing one's home. ${ }^{157}$

With a proper definition of 'home', charged with legal potency and tenacity, it may firmly stand against potential threats. It may also inadvertently aggrandise the enforceability of Art 8. While there are

150 L Fox Conceptualising Home: Theories, Laws and Policies (Oxford: Hart Pub, 2007).

${ }^{151}$ Ibid, p 483.

152 R Lawrence "Deciphering Home: An Integrative Historical Perspective” in DN Benjamin The Home: Words, Interpretations, Meanings and Environments, (Aldershot, Ashgate, 1995) p 58.

${ }^{153}$ L Fox, above n 150, p 24.

154 [1986] ECHR 14.

155 Ibid, para [55]; see also JD Porteous "Domicide; The Destruction of Home” in DN Benjamin The Home: Words, Interpretations, Meanings and Environments, above $\mathrm{n}$ 114, and M Fried “Grieving for a Lost Home” in J Duhl The Urban Condition People and Policy in Metropolis (New York, Basic Books, 1963).

${ }^{156}$ Qazi, above n 95, para [8].

${ }^{157}$ Illuminated in L Fox Conceptualising Home, above n 150, p 8; see Governmental white paper Development and Compensation - Putting People First (Cmnd 5124), (London, HSMO, 1972). 
mortgagors who have lost their homes due to faults of their own; there are also those who are victims of unfortunate and unpredicted circumstances and in the direct hands of a failing financial market. Having actively encouraged home-ownership and enabled unscrupulous lending practices, where lies the state's responsibility for the consequences of its policies?

Going back to the proportionality principle and scrutinising whether the degree of mortgage deregulation and protection awarded to secured lenders are necessary, its support may not be as strong in our contemporary housing market. The CML continuously emphasise that any attempts to curtail the rights granted to lenders "would have severe consequences for the lending industry and therefore the borrower and for the economy as a whole". ${ }^{158}$ Indeed, this response was one of the reasons why the draft Pre-Action Protocol failed, leaving the revised Protocol toothless. However, the CML's contention is not necessarily true and in any event should not be taken for granted. While arguing for a fairer balance between mortgagors and mortgagees in repossession proceedings, Smith informs us that as mortgagees in the twenty-first century "appear to be more enthusiastic when it comes to lending money ... than ever before", ${ }^{159}$ the anticipated fear of restrained mortgage availability due to regulatory and legal measures may not be as acute as previously contended.

In regards to inadequate legal protection, is the disproportionate level of protection afforded to mortgagees under S 36 AJA 1979 necessary to safeguard the mortgagees' contractual rights? As illustrated above, balancing the contractual interests fairly by reformulating the right to repossession to a remedy, attainable upon court order, would still effectively protect the mortgagees' interest if need be, but crucially also properly reflect the interest of one's home. As noted, this has not only been proposed extensively by academics, it has found support by the Law Commission and judiciary alike. ${ }^{160}$ Furthermore, the UK courts have now conceded to the fact that in the sphere of public renting, lawful possession proceedings are capable of being

${ }^{158}$ Council of Mortgage Lenders Mortgage Remedies (Possession and Sale) Review Response by the Council of Mortgage Lenders to the Ministry of Justice's Initial Review (14 January 2009).

159 S Smith Banking and Housing: Speculating the Role and Relevance of Housing Wealth in Britain, paper prepared for the Joseph Rowntree Foundation Inquiry into Home ownership 2010 and beyond, 2005, p 4.

160 See Law Commission's Working Paper Land Mortgages, (Number 99, 1986, paragraph 3.69) which got published in its Report Transfer of Land - Land Mortgages, (1991) Law Com No 204; See also, for instance, Clarke LJ comments in Ropaigealach, above n 30, at 283. 
challenged where 'exceptional circumstances' exist, ${ }^{161}$ questioning why similar considerations should not be extended to mortgagors.

\section{APPROPRIATE ACTION}

In Moreno Gomez, the applicant had suffered a serious infringement of her Art 8 rights as the state had failed in its positive obligation to effectively regulate private actors' actions. This text has argued that repossessed mortgagors has potentially suffered an infringement of their Art 8 rights as the UK has failed in its positive obligation to provide adequate legal protection and an effective regulatory framework. By holding the UK accountable under Art 8 the ECHR might demand a remedy for the applicant in the instant case. Indicatively, in Moreno Gomez the applicant was awarded 3005 euro in nonpecuniary damages, 4000000 Ptas (appr. 24000 euro) in Lopez-Ostra, and 14000 euro in Connors. Certainly, mortgagors cannot be allowed to remain in their homes if they cannot afford it as it would severely undermine the contractual rights of mortgagees and the economy. What must be done here is to hinder these instances arising from the first place, ie the UK must take a proactive approach to protect the homes of its citizens. In order to respect, protect and fulfil the mortgagors Art 8 rights effectively, not illusively, the UK must establish a legal framework that strikes the right balance between the mortgagees' and mortgagors' interests, going beyond the mere financial test under S 36 AJA 1970, and instigate a regulatory framework that effectively rein in miscreant lenders and ensures that a home is not lost unnecessarily. By tightening lending regulation and providing it with legal backing, we can minimise the risks involved when lending to financially incapable individuals. Further, transforming the right to possession to a remedy, obtained through court order, would force the mortgagee to be wary of its lending practices.

However, this does not suffice. The UK must take full responsibility for the effect of its housing policy. As we have seen, its encouragement of homeownership has, due to residualisation, rendered few alternatives to satisfy the 'deep-rooted desire' for 'home'. If the UK will, as this text demands, tighten lending practices it will naturally lead to inaccessibility of home-ownership for a section of the society who do not live up to the minimum lending criteria. This group of people must be provided rented accommodation which can readily satisfy the requirements of 'home', such as security, comfort and pride. Therefore, what the UK should to do is scrap their encouragement of home-ownership and replace it with a home-security policy. Rather than

161 See Lord Bingham in Kay and Price, above n 108, para [35], reiterating Lord Millet in Qazi, above n 95, para [100]. 
aiming towards home-ownership, the home-security policy would aim towards sustainable home tenure, regardless of its origin. Governments during the $20^{\text {th }}$ century might have been right in claiming that home-ownership is a deep-rooted desire ingrained in the hearts of UK citizens. What the government is ultimately responsible for, however, is the formation of policies that correspond with the realities of contemporary politics, economics and culture. Denying home-ownership to financially incapable individuals is not being hard or arbitrary; it is being fair, true and prudent.

\section{CONCLUSION}

The mortgage relationship is comprised of mutual benefits. The mortgagee provides the means by which individuals realise their desire of becoming home-owners and enables a release of capital fixed in the property. The mortgagor assures a steady flow of income for the mortgagee, where the end capital paid surmounts that of the loan made, thereby creating a profit. It is a clever relationship, indeed.

Regretfully, this relationship has been tainted by the failure of the state to prevent unscrupulous lenders exploiting the vulnerability of some aspiring home-owners. The creation of the ECHR was born out of a quest to safeguard human dignity against potential threats. This text has illuminated that one of those threats has been the UK's failure to protect mortgagors' homes. With the aim of becoming a 'property owning democracy', successive governments have financially encouraged the acquisition of mortgage finance, however, failed to implement corresponding legal protection and effective regulatory framework to curtail unscrupulous mortgagees, leading to deprivation of homes.

To hold the UK responsible for this failure, this text has turned to ECHR jurisprudence relating to the doctrine of positive obligations. We have seen through cases such as Lopez-Ostra, Moreno Gomez and Moldovan that the ECHR has not only recognised the existence of a positive obligation under Art 8 , but also that such an obligation may arise to regulate the behaviour between private actors. We have also seen through cases such as Connors, McCann and Cosic an increasing determination on the part of ECHR to reinforce rights emanating from Art 8 by subjecting domestically lawful possession proceedings undertaken by public authorities to Art 8 (2) scrutiny. Building on these two developments, this text has argued that the conjunctive factors of state encouragement of home-ownership, financial deregulation, inadequate legal protection and an ineffective regulatory framework have precipitated home repossessions to the extent that the UK may be in violation of its positive obligations under Art 8 . This is particularly attainable if the concept of 'home' gets upgraded to its true colours in order to counteract its principal 
opponents under Art 8 (2); that is, the state's margin of appreciation in respecting the contractual rights of the mortgagee and protecting the economy as a whole.

Undeniably, the assertions in this text are quite polemical and at times possibly unrealistic. However, the questions asked and the thoughts provoked are necessary in our society today. As the state has perniciously retreated, private actors have stepped in and filled the vacuum. The one court that stands up for the individual must start asking the same questions as this text. Understandably, given the intrusiveness upon state sovereignty that my proposed route entails and the conceptual difficulties involved, an applicant will find it hard to successfully argue their case. Nonetheless, importantly, Scott and Macklam suggest, as long as the Court holds the case admissible and scrutinises the issues raised, it might be all that is needed to provoke action. ${ }^{162}$ This is called 'soft enforcement' which is particularly pertinent in relation to socio-economic rights where the court will find it difficult to demand positive measures. As the Canadian case of Askov ${ }^{163}$ demonstrates, constructively criticising the issues at hand but stopping short of demanding positive measures can have huge political impact. ${ }^{164}$ Another prime example of this is the Indian case of Olga Tellis ${ }^{165}$ which is famous for shedding light on India's housing problem and illustrates how judicial activism triggers political action.

In 2008, 40000 homes were repossessed in the UK, 46000 in 2009 and by the end of 2010 an additional estimated 53000 homes will get repossessed. ${ }^{166}$ Something must be done. In the midst of financial deregulation, competitiveness, specialisation, innovation, and growth, the UK lost its way and forgot who, under the social contract, it ultimately answers to. Let us hope the UK will come to remember its promised responsibility to protect its people.

\footnotetext{
${ }^{162} \mathrm{C}$ Scott and P Macklam, above n 75.

163 [1990] 2 SCR 1199, 1203-1207, 1247 (Can), see esp. paras [1241]-[1243].

${ }^{164}$ See also TD v Minister for Education [2001] 4 IR 259, Ir. SC.

165 Olga Tellis v Bombay Municipal Corp [1986] AIR 1.

166 See repossession statistics from Council of Mortgage Lenders, available at http://www.cml.org.uk/cml/media/press/2541.
} 